\title{
On the finding of zincohögbomite in the granite pegmatites of the Lipovskiy vein field (Middle Urals)
}

\author{
Anatoliy Vladimirovich ZAKHAROV
}

The Zavaritsky Institute of Geology and Geochemistry of the Ural Branch of RAS, Ekaterinburg, Russia

\section{Abstract}

The relevance of the work is due to the need to study the mineralogy of granite pegmatites of the Lipovskiy vein field, a unique object that gave the world a large amount of crystal raw materials of colored tourmaline

Purpose of the work: study of zincohögbomite found in granite pegmatites of the Lipovskiy vein field (Middle Urals). Research methodology: quantitative analysis of the chemical composition of magnetite was carried out using the X-ray spectral electron probe microanalyzer CAMECA SX 100 (The Zavaritsky Institute of Geology and Geochemistry of the Ural Branch of the Russian Academy of Sciences, Ekaterinburg). The chemical composition of zincohögbomite was determined using the Jeol JSM-6390LV scanning electron microscope with an INCA Energy 450 X-Max 80 energy dispersive attachment from Oxford Instruments (The Zavaritsky Institute of Geology and Geochemistry of the Ural Branch of the Russian Academy of Sciences, Ekaterinburg).

Results. When studying the surface of magnetite crystals, pore spaces were found inlaid with flattened grains of an unknown mineral, mainly triangular, less often hexagonal, in shape, up to 2-3 microns in size. Based on the data on its chemical composition, this mineral was assigned to zincohögbomite. Based on crystallochemical calculations, it was found that the mineral corresponds to zincohögbomite-2H2S or zincohögbomite- $8 \mathrm{H}$ according to the old classification.

Conclusions. A new mineral was found for granite pegmatites of the Lipovskiy vein field - zincohögbomite-2H2S. It was found in the form of inclusions in magnetite individuals in common intragranite pegmatites. This is the second find of zincohögbomite in the Urals and, most likely, the first one in the world in granite pegmatites. The formation of zincohögbomite is associated with retrograde metamorphism of amphibolite facies, when primary spinels become unstable and decompose into several mineral phases. Zincohögbomite from Lipovskiy field was formed as a result of the decomposition of primary magnetite during the cooling of granite pegmatite.

Keywords: zincohögbomite, magnetite, granitic pegmatites, Lipovskiy vein field, Middle Urals.

Introduction

Zincohögbomite is a rare mineral and has not been described in the Urals until recently. Although there was a mention of its discovery in the Nikolay-Maximilian mines of the Southern Urals [1], but as it turned out later, it was zinc-bearing magnesiohögbomite with a low $\mathrm{ZnO}$ content of up to 11.12 wt.\% [2]. In 2018, zincohögbomite was found in corundum-bearing plagioclasites of the Rai-Iz hyperbasite massif (Polar Urals) in cavities titanomagnetite segregations in association with rutile, ilmenite, and hercynite [3]. The present work describes the first finding of zincohögbomite in granite pegmatites of the Lipovskiy vein field.

Geological position of the research object

Granite pegmatites of the Lipovskiy vein field are located on the eastern slope of the Middle Urals (70 km northeast of Ekaterinburg and $2 \mathrm{~km}$ west of the Lipovskoe village). The world-famous and then abandoned deposit of pink tourmalines (rubellites) is associated with them. Pegmatites are confined to a gently sloping synclinal structure sandwiched between three large granite massifs - Murzinskiy (from the north-west), Aduyskiy (from the south-west) and Sokolovskiy (from the east). The syncline itself is composed of Proterozoic metamorphic rocks, which are dominated by various gneisses, schists, and amphibolites [4, 5, etc.]. Separate bodies of serpentinites and marbles are also noted here, which are usually tectonically interspersed with each other in the melange zone. A well-known and then abandoned deposit of silicate-nickel ores is associated with karst marbles and weathering crusts of serpentinites. Granite pegmatites are widespread within the Lipovskiy vein field and are usually represented by ordinary (intragranite), lithium-bearing, and desilicated types. The age of intragranite rare-metal pegmatites was determined in the range of $266.4 \pm 2.6 \mathrm{Ma}$ [6].

Methods of research

A quantitative analysis of the chemical composition of magnetite was carried out using the CAMECA SX 100 electron probe microanalyzer (The Zavaritsky Institute of Geology and Geochemistry of the Ural Branch of the Russian Academy of Sciences, Ekaterinburg, analyst V. V. Khiller). Polished thin sections were made from rock fragments, then they were sprayed with a thin layer of carbon. Measurement conditions: accelerating voltage is $15 \mathrm{kV}$, current is $50 \mathrm{nA}$, electron beam diameter is $2 \mu \mathrm{m}$. Standard samples were used for the analysis.

$\triangle$ zakharov-zav@yandex.ru

https://orcid.org/0000-0001-8790-7892 


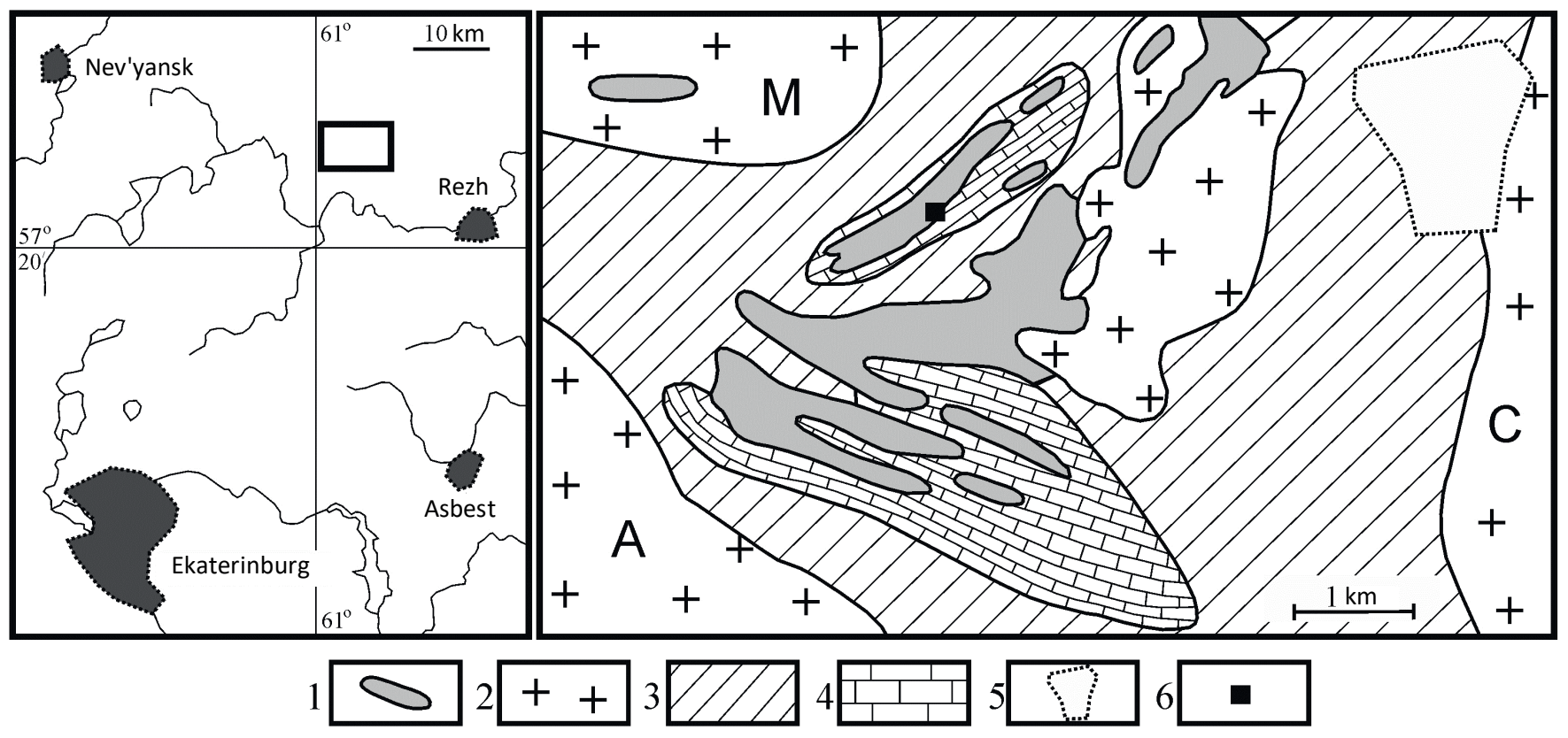

Figure 1. Geological scheme of the Lipovskiy vein field (given after [4] with additions by the authors). 1 - serpentinites; 2 - granites (A - Aduyskiy massif, M - Murzinskiy massif, C - Sokolovskiy massif); 3 - gneisses; 4 - marbles; 5 - the outlines of the Lipovskoye village; 6 outcrops of the studied granite pegmatite.

Рисунок 1. Геологическая схема Липовского жильного поля (дано по [4] с авторскими добавлениями): 1 - серпентиниты; 2 - граниты (А - Адуйский массив, М - Мурзинский массив, С - Соколовский массив); 3 - гнейсы; 4 - мраморы; 5 - контуры деревни Липовское; 6 - выходы изученного гранитного пегматита.

The intensity was recorded using the $K \alpha$ lines on inclined wave spectrometers ( $40 \mathrm{x}$-ray sampling angle) with analyzer crystals TAP (for $\mathrm{Mg}, \mathrm{Al}, \mathrm{Si}$ ), LPET (Ca, Ti, $\mathrm{Cr}$ ) and $\mathrm{LiF}$ (Mn, Fe, etc.).

The chemical composition of zincohögbomite was determined using the Jeol JSM-6390LV scanning electron microscope with an INCA Energy 450 X-Max 80 energy dispersive attachment from Oxford Instruments (The Zavaritsky Institute of Geology and Geochemistry of the Ural Branch of the Russian Academy of Sciences, Ekaterinburg, analyst L. V. Leonova).

\section{Research results and discussion}

Zincohögbomite was found by us in the form of inclusions in magnetite in a vein of rare-metal ordinary granite pegmatite in the southwestern edge of the abandoned quarry No. 6 of the Lipovskiy nickel deposit (GPS reference - N 57 $26^{\prime} 32.6^{\prime \prime}$ , E $061^{\circ} 06^{\prime} 08.6^{\prime \prime}$, see Fig. 1). The body is traced at a distance of $50 \mathrm{~m}$, parallel to the edge of the quarry, the thickness of the pegmatite ranges from 2 to $2.5 \mathrm{~m}$. The vein is gently dipping with an angle of incidence of $15-20^{\circ}$ to the southwest. Vein structure is zonal. The upper part of the pegmatite body is composed of aplite, up to $0.5 \mathrm{~m}$ thick. The composition is predominantly plagioclase-quartz with an insignificant content of mica. Gradually, the aplite zone is replaced by two-feldspar pegmatite, which also contains an insignificant amount of mica, the size of mica grains often exceeds $1 \mathrm{~cm}$. Here, large grains of potassium feldspar and plagioclase up to $2 \mathrm{~cm}$ are also observed. Pegmatite contains small lenses consisting of spruce-like mica aggregates.

Pegmatite is then replaced by the aplite zone, but less defined in comparison with the upper part. The thickness of aplite is $10-15 \mathrm{~cm}$. The central part of the body is composed of graphic pegmatite with abundant garnet and rarer magnetite. Closer to the central part, individual chrysoberyl grains are found. The thickness of the graphic zone reaches $1 \mathrm{~m}$. Almost monomineralic lenticular accumulations of fine-grained albite, with muscovite growing into it, are observed under the mica nests in the mass of graphic pegmatite. In the central part of many albite formations, quartz cores are observed, up to 15 $\mathrm{cm}$ in diameter, with chrysoberyl and rarely beryl. There is a zone of graphic pegmatite below, up to $0.5 \mathrm{~m}$ thick (see Fig. 2). It is replaced by quartz lenses (separated by pegmatite) or small mica fringes. Crystals of black tourmaline (schorl) up to $10 \mathrm{~cm}$ long are observed on contact with the phlogopite rim. Below there is a contact zone of mica with a thickness of 5 to $15 \mathrm{~cm}$; it contains separate well-formed crystals of tourmaline, no more than $2-3 \mathrm{~cm}$ in size $[7,8]$.

Magnetite grains are dispersed throughout the matrix of granite pegmatite and compose buildups up to $1 \mathrm{~cm}$ in diameter. Usually they are xenomorphic, but they have the appearance of an octahedral crystal. The color is black, gravitated to the magnet. The chemical composition of magnetite is fairly consistent and clean. According to microprobe analysis, the following impurities are noted in the mineral: chromium $\left(\mathrm{Cr}_{2} \mathrm{O}_{3}\right.$ up to $\left.0.6 \mathrm{wt} \%\right)$, manganese ( $\mathrm{MnO}$ up to $\left.0.4 \mathrm{wt} \%\right)$, aluminum $\left(\mathrm{Al}_{2} \mathrm{O}_{3}\right.$ up to $\left.0.3 \mathrm{wt} \%\right)$, silicon $\left(\mathrm{SiO}_{2}\right.$ up to $\left.0.3 \mathrm{wt} \%\right)$ and titanium $\left(\mathrm{TiO}_{2}\right.$ up to $0.2 \mathrm{wt} \%$ ) (see Table 1). Barite is found in association with magnetite (Fig. 3). Using a scanning microscope, the magnetite surface looks spongy and loose, the pore size is no more than 1-2 microns. The pores are almost always elongated and either hollow or filled with a silicate matrix (probably chlorite). Simultaneously with small pores in the magnetite matrix, there are also larger pore spaces, up to 10-15 microns in size and very rarely up to 50-100 microns, with clear crystallographic six- and octahedral outlines (probably so-called negative crystals). 


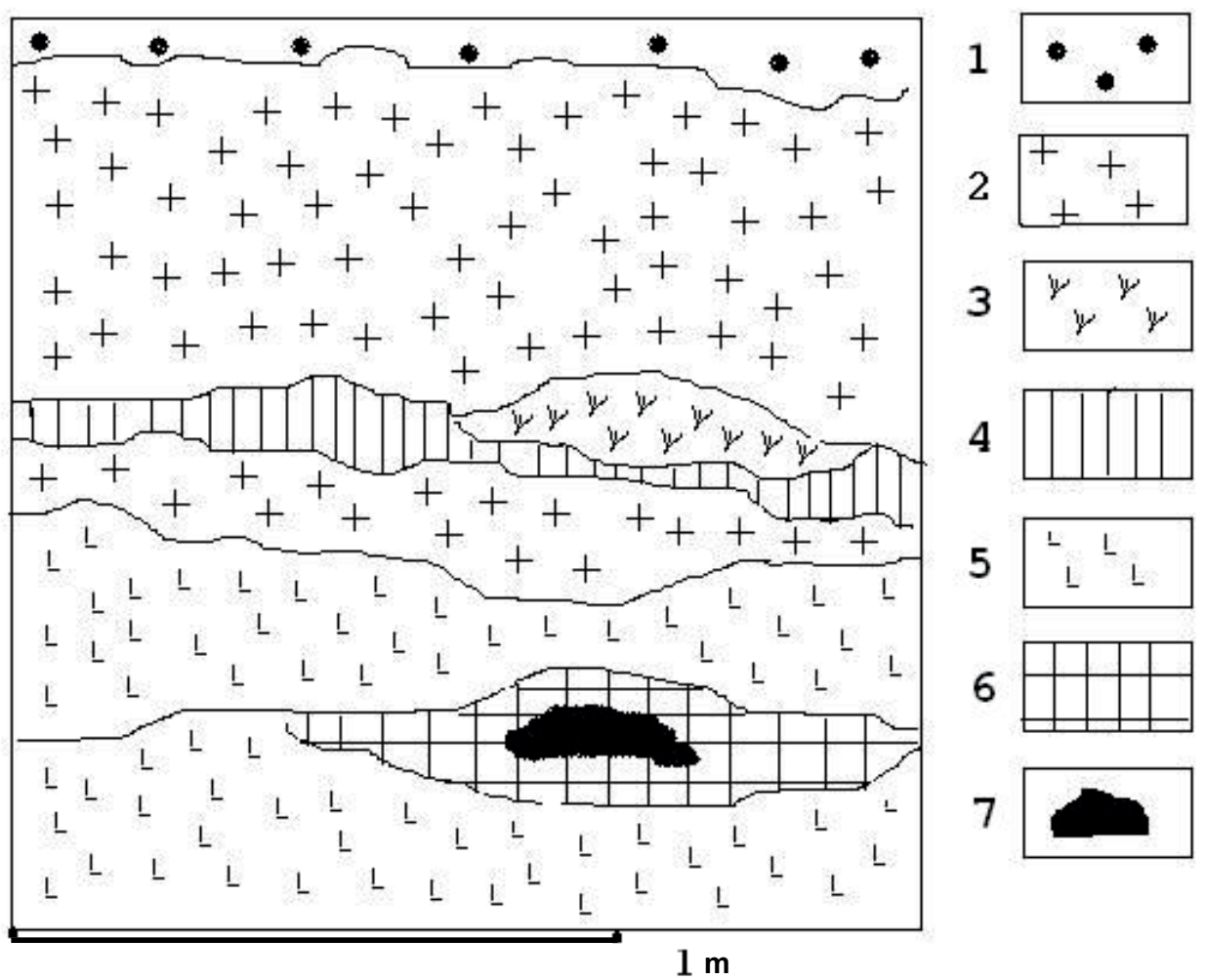

Figure 2. Schematic structure of the upper part of the pegmatite vein: 1 - soil cover; 2 - aplite; 3 - mica core; 4 - pegmatite without graphic; 5 - graphic granite; 6 - aggregations of albite; 7 - quartz core.

Рисунок 2. Схематическое строение верхней части пегматитовой жилы: 1 - почвенный покров; 2 - аплит; 3 - слюдяное ядро; 4 пегматит без графики; 5 - графический пегматит; 6 - скопления альбита; 7 - кварцевое ядро.

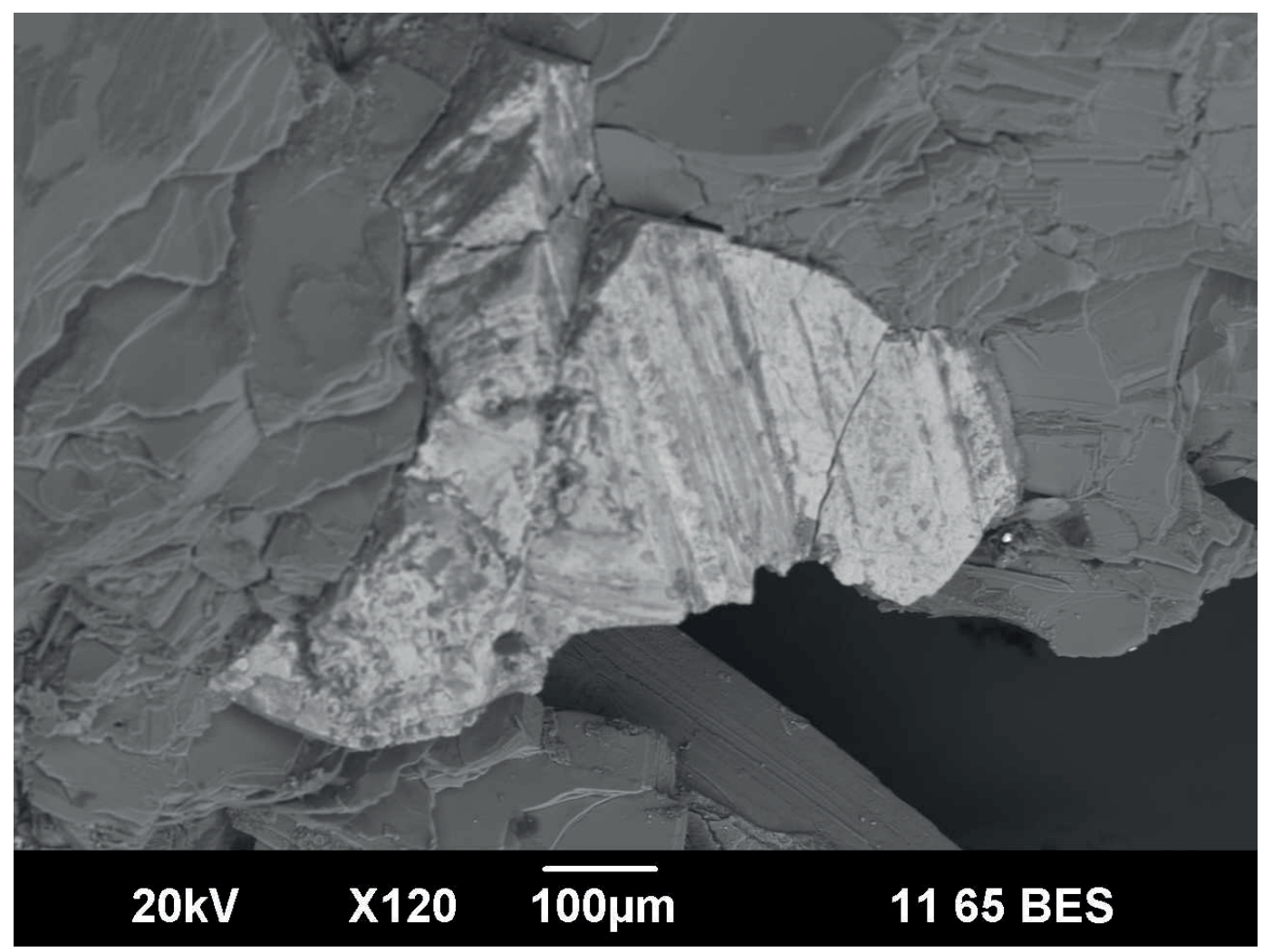

Figure 3. Magnetite grain (light gray) in a quartz-feldspar matrix (dark gray). The bright spot to the right of magnetite is barite. BSE image, JSM-6390LV scanning electron microscope.

Рисунок 3. Зерно магнетита (светло-серое) в кварц-полевошпатовой матрице (темно-серое). Яркая точка справа от магнетита является баритом. BSE-изображение, сканирующий электронный микроскоп JSM-6390LV. 
Table 1. Chemical composition of magnetite from granite pegmatite, wt\%.

Таблица 1. Химический состав магнетита из гранитного пегматита, мас.\%.

\begin{tabular}{|c|c|c|c|c|c|c|c|c|c|c|}
\hline \multirow{2}{*}{ No. } & \multicolumn{10}{|c|}{ Oxides } \\
\hline & $\mathrm{SiO}_{2}$ & $\mathrm{TiO}_{2}$ & $\mathrm{Al}_{2} \mathrm{O}_{3}$ & $\mathrm{Cr}_{2} \mathrm{O}_{3}$ & $\mathrm{Fe}_{2} \mathrm{O}_{3}$ & $\mathrm{FeO}$ & $\mathrm{MnO}$ & $\mathrm{MgO}$ & $\mathrm{CaO}$ & Total \\
\hline 1 & 0.30 & 0.18 & 0.29 & 0.58 & 66.66 & 31.32 & 0.17 & 0.02 & 0.05 & 99.57 \\
\hline 2 & 0.05 & 0.15 & 0.21 & 0.15 & 67.93 & 30.99 & 0.20 & - & 0.02 & 99.70 \\
\hline 3 & 0.18 & 0.18 & 0.27 & 0.60 & 66.58 & 30.79 & 0.38 & 0.02 & 0.03 & 99.03 \\
\hline 4 & 0.13 & - & 0.05 & - & 67.50 & 30.40 & 0.33 & - & - & 98.41 \\
\hline 5 & 0.06 & 0.04 & 0.03 & 0.07 & 68.05 & 30.53 & 0.38 & - & 0.01 & 99.17 \\
\hline
\end{tabular}

Note: Analyzes were performed using CAMECA SX 100 (The Zavaritsky Institute of Geology and Geochemistry of the Ural Branch of the Russian Academy of Sciences, analyst V. V. Khiller); ferric iron is calculated according to the stoichiometry of the mineral.

Примечание: анализы сделаны на САМЕСА SX 100 (ИГГ УрО РАН, аналитик В. В. Хиллер); трехвалентное железо рассчитано согласно стехиометрии минерала.

Table 2. Chemical composition of zincohögbomite from granite pegmatite, wt\%.

Таблица 2. Химический состав цинкохёгбомита из гранитного пегматита, мас.\%.

\begin{tabular}{|c|c|c|c|c|c|c|c|c|}
\hline \multirow{2}{*}{ No. } & \multicolumn{8}{|c|}{ Oxides } \\
\hline & $\mathrm{Al}_{2} \mathrm{O}_{3}$ & $\mathrm{TiO}_{2}$ & $\mathrm{MnO}$ & $\mathrm{FeO}$ & $\mathrm{NiO}$ & $\mathrm{CuO}$ & $\mathrm{ZnO}$ & Total \\
\hline 1 & 50.69 & 9.31 & 0.42 & 12.60 & 0.31 & 0.36 & 26.30 & 100.00 \\
\hline 2 & 51.16 & 7.75 & 0.46 & 12.80 & 0.23 & 0.47 & 27.13 & 100.00 \\
\hline 3 & 53.23 & 12.00 & 0.43 & 9.36 & - & - & 24.98 & 100.00 \\
\hline \multicolumn{9}{|c|}{ Crystal chemical formulas for 16 oxygen atoms } \\
\hline 1 & \multicolumn{8}{|c|}{$\left(\mathrm{Zn}_{1.39} \mathrm{Al}_{0.79} \mathrm{Fe}_{0.75} \mathrm{Mn}_{0.03} \mathrm{Cu}_{0.02} \mathrm{Ni}_{0.02}\right)_{3.00}\left(\mathrm{Al}_{7.74} \mathrm{Ti}_{0.50}\right)_{8.24} \mathrm{O}_{15}(\mathrm{OH})$} \\
\hline 2 & \multicolumn{8}{|c|}{$\left(\mathrm{Zn}_{1.43} \mathrm{Fe}_{0.76} \mathrm{Al}_{0.74} \mathrm{Mn}_{0.03} \mathrm{Cu}_{0.03} \mathrm{Ni}_{0.01}\right)_{3.00}\left(\mathrm{Al}_{7.87} \mathrm{Ti}_{0.42}\right)_{8.29} \mathrm{O}_{15}(\mathrm{OH})$} \\
\hline 3 & \multicolumn{8}{|c|}{$\left(\mathrm{Zn}_{1.27} \mathrm{Al}_{1.16} \mathrm{Fe}_{0.54} \mathrm{Mn}_{0.03}\right)_{3.00}\left(\mathrm{Al}_{7.46} \mathrm{Ti}_{0.62}\right)_{8.08} \mathrm{O}_{15}(\mathrm{OH})$} \\
\hline \multicolumn{9}{|c|}{ Crystal chemical formulas for 32 oxygen atoms } \\
\hline 1 & \multicolumn{8}{|c|}{$\left(\mathrm{Zn}_{2.77} \mathrm{Al}_{2.60} \mathrm{Fe}_{1.50} \mathrm{Mn}_{0.05} \mathrm{Cu}_{0.05} \mathrm{Ni}_{0.03}\right)_{7.00}\left(\mathrm{Al}_{14.47} \mathrm{Ti}_{1.00}\right)_{15.47} \mathrm{O}_{31}(\mathrm{OH})$} \\
\hline 2 & \multicolumn{8}{|c|}{$\left(\mathrm{Zn}_{2.86} \mathrm{Al}_{2.47} \mathrm{Fe}_{1.53} \mathrm{Mn}_{0.06} \mathrm{Cu}_{0.05} \mathrm{Ni}_{0.03}\right)_{7.00}\left(\mathrm{Al}_{14.74} \mathrm{Ti}_{0.83}\right)_{15.57} \mathrm{O}_{31}(\mathrm{OH})$} \\
\hline 3 & \multicolumn{8}{|c|}{$\left(\mathrm{Al}_{3.34} \mathrm{Zn}_{2.53} \mathrm{Fe}_{1.08} \mathrm{Mn}_{0.05}\right)_{7.00}\left(\mathrm{Al}_{13.90} \mathrm{Ti}_{1.24}\right)_{15.14} \mathrm{O}_{31}(\mathrm{OH})$} \\
\hline
\end{tabular}

Note: Analyzes were performed using the JSM-6390LV scanning electron microscope (The Zavaritsky Institute of Geology and Geochemistry of the Ural Branch of the Russian Academy of Sciences, analyst L. V. Leonova).

Примечание: анализы сделаны на сканирующем электронном микроскопе JSM-6390LV (ИГГ УрО РАН, аналитик Л. В. Леонова).

These large pore spaces are made by differently oriented plates, generally triangular, less often hexagonal in shape, up to $2-3 \mu \mathrm{m}$ in size (Fig. 4). They form both monomineralic accumulations and intergrowths with another mineral, most likely, ilmenite. The chemical composition of plates is characterized by a fairly consistent composition (see Table 2) with high contents of zinc ( $\mathrm{ZnO} 25-27$ wt.\%), aluminum $\left(\mathrm{Al}_{2} \mathrm{O}_{3}\right.$ 50-53 wt.\%), iron ( $\mathrm{FeO} 9-13$ wt.\%) and titanium $\left(\mathrm{TiO}_{2} 9-12\right.$ wt.\%), which allows us to confidently refer it to zincohögbomite. Copper ( $\mathrm{CuO}$ up to $0.5 \mathrm{wt} \%$ ), manganese ( $\mathrm{MnO}$ up to 0.5 wt $\%$ ) and nickel ( $\mathrm{NiO}$ up to $0.3 \mathrm{wt} \%$ ) are noted among impurities in the mineral.

Zincohögbomite is a polysomatic series of minerals, expressed in a certain alternation in the structure of layers of an iron analogue of nolanite, $\left(\mathrm{V}^{3+}, \mathrm{Fe}^{3+}, \mathrm{Fe}^{2+}\right)_{10} \mathrm{O}_{14}(\mathrm{OH})_{2}(\mathrm{~N})$ and zinc spinel (ganite), $\mathrm{ZnAl}_{2} \mathrm{O}_{4}$ (S). At present, two minerals are distinguished in the taxonomy - zincohögbomite-2N2S and zincohögbomite-2N6S [9], and this division is carried out according to the results of X-ray structural studies. Unfortunately, the grain size of our zincohögbomite does not allow for analytical measurements of structural parameters to a mineral form, but there is an indirect sign of determining the mineral by its chemical composition. So, for two minerals - zincohögbomite-2N2S and zincohögbomite-2N6S, different formulas are given $(\mathrm{Zn}, \mathrm{Al}, \mathrm{Fe})_{3}\left(\mathrm{Al}, \mathrm{Fe}^{3+}, \mathrm{Ti}\right)_{8} \mathrm{O}_{15}(\mathrm{OH})$ and $(\mathrm{Zn}, \mathrm{Al})_{7}(\mathrm{Al}, \mathrm{Fe}$ $\left.{ }^{3+}, \mathrm{Ti}, \mathrm{Mg}\right)_{16} \mathrm{O}_{31}(\mathrm{OH})$ (according to the MMA mineral database, May 2020), respectively. This is quite obvious, since in minerals, the number of layers of zinc spinel changes, which means 


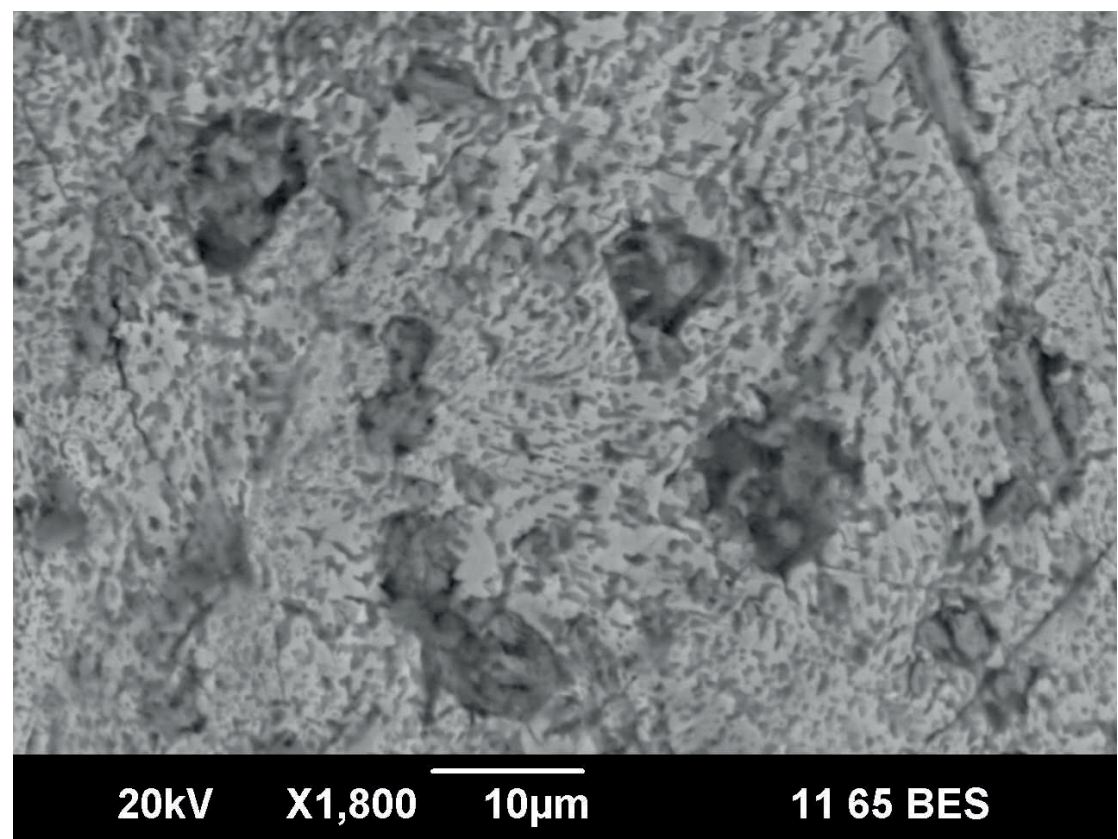

Figure 4. Open pore spaces in the spongy matrix of magnetite (light gray), inlaid with plates of zincohögbomite (dark gray). BSE image, JSM-6390LV scanning electron microscope.

Рисунок 4. Открытые полости в ноздреватой матрице магнетита (светло-серое), инкрустированные пластинками цинкохёгбомита (темно-серое). BSE-изображение, сканирующий электронный микроскоп JSM-6390LV.

that there is a difference in the content of alumina, zinc and iron. If we compare the compositions of two typical zincohögbomites $[10,11]$, then the mineral from Lipovskiy vein field according to the data of crystallochemical recalculations (see Table 2) quite well corresponds to zincohögbomite-2N2S or zincohögbomite-8H according to the old classification.

In general, zincohögbomite was described in metamorphosed bauxites [12-14] and sulfide ores [15], dolomite marbles [11], and apobasitic chlorite boudins from serpentinites [16]. Thus, our find of zincohögbomite in granite pegmatites is unusual and has not been previously described in the world. The formation of högbomite is associated with retrograde metamorphism of the amphibolite facies [17 etc.], when the primary minerals from the spinel group become unstable and disintegrate into several mineral phases, which actually happened in our case when the granite pegmatite cooled.

Conclusions

Thus, we have identified a new mineral for the granite pegmatites of the Lipovskiy vein field - zincohögbomite-2N2S or, according to the old classification, zincohögbomite- $8 \mathrm{H}$. It was found in the form of inclusions in magnetite grains in common intragranite pegmatites. This is the second find of zincohögbomite in the Urals and, most likely, the first one in the world in granite pegmatites.

The author thanks the management of the Rezhevskiy State Natural Mineralogical Reserve (OGUMPZ "Rezhevskoy"), as well as Ph.D. Yu. V. Erokhin, Ph.D. L. V. Leonova and candidate of geological and mineralogical sciences V. V. Khiller for assistance with research.

The work was carried out within the framework of the state assignment of the Zavaritsky Institute of Geology and Geochemistry of the Ural Branch of the Russian Academy of Sciences, no. AAAA-A18-118052590032-6.

\section{REFERENCES}

1. Moleva V. A., Myasnikov V. S. 1952, About högbomite and zincohögbomite as its variety. Doklady Akademii nauk [Doklady Earth Sciences], vol. 82, no. 5, pp. 733-735. (In Russ.)

2. Kobyashev Yu. S. 2006, List of minerals of the Urals (types and varieties). Ural'skiy geologicheskiy zhurnal [Uralian geological journal], no. 2 (50), pp. 1-265. (In Russ.)

3. Erokhin Yu. V., Vakhrusheva N. V. 2018, O nakhodke tsinkokhogbomita-2N2S v plagioklazitovykh zhilakh massiva Ray-Iz (Polyarnyy Ural) [On the finding of zincohögbomite-2N2S in plagioclasite veins of the Ray-Iz massif (Polar Urals)]. VII Readings in memory of corresponding member of RAS S. N. Ivanov. Proceedings of the All-Russian scientific conference dedicated to the 70th anniversary of the foundation of the Ural Branch of the Russian Mineralogical Society. Ekaterinburg, pp. 66-68.

4. Emlin E. F., Vakhrusheva N. V., Kaynov V. I. 2002, Semiprecious streak of the Urals: Rezhevskoy state natural and mineralogical reserve. Guide. Ekaterinburg; Rezh, 156 p.

5. Pekov I. V., Memetova L. R. 2008, Minerals of Lipovka granite pegmatites, Middle Urals. In the world of minerals. Mineralogical almanac, no. 13, pp. 7-44.

6. Khiller V. V., Erokhin Yu. V., Zakharov A. V., Ivanov K. S. 2014, Th-U-Pb dating of granite pegmatites of the Lipovskiy ore field (Urals) based on three minerals. Doklady Akademii nauk [Doklady Earth Sciences], vol. 455, no. 2, pp. 216-219. (In Russ.)

7. Zakharov A. V., Khanin D. A. 2012, New data on chrysoberyl from pegmatites of the Lipovskiy vein field (Middle Urals). Vestnik Ural'skogo 
otdeleniya RMO [Bulletin of the Ural Branch of the Russian Mineralogical Society], no. 9, pp. 68-74. (In Russ.)

8. Khanin D. A., Zakharov A.V. 2012, Granite pegmatite with accessory chrysoberyl from quarry No. 6 of the Lipovskiy silicate-nickel deposit. International scientific and practical conference "Ural Mining School - to the Regions". Ekaterinburg, pp. 54-55.

9. Armbruster Th. 2002, Revised nomenclature of högbomite, nigerite, and taaffeite minerals // European Journal of Mineralogy, vol. 14, pp. 389-395. https://doi.org/10.1127/0935-1221/2002/0014-0389

10. Armbruster Th. 1998, Zincohogbomite-8H from Samos (Greece): crystal structure, polysomatism, and polytypism in hogbomite related structures. Schweizerische Mineralogische und Petrographische Mitteilungen, vol. 78, no. 3, pp. 461-468.

11. Armbruster Th., Bermanec V., Zebec V., Oberhänsli R. 1998, Titanium and iron poor zincohögbomite-16H, $\mathrm{Zn}_{14}\left(\mathrm{Al}_{1}, \mathrm{Fe}^{3+}, \mathrm{Ti}, \mathrm{Mg}\right)_{8} \mathrm{Al}{ }_{24} \mathrm{O}_{62}(\mathrm{OH})_{2}$ from Nezilovo, Macedonia: occurrence and crystal structure of a new polysome. Schweizerische Mineralogische und Petrographische Mitteilungen, vol. 78, no. 3, pp. 469-477.

12. Ockenga E., Yalçin Ü., Medenbach O., Schreyer W. 1998, Zincohögbomite, a new mineral from eastern Aegean metabauxites. European Journal of Mineralogy, vol. 10, pp. 1361-1366. URL: https://www.mindat.org/min-26091.html

13. Feenstra A. 1997, Zincohögbomite and gahnite in a diaspore-bearing metabauxite from eastern Samos (Greece): mineral chemistry, element partitioning and reaction relations. Schweizerische Mineralogische und Petrographische Mitteilungen, vol. 77, pp. 73-93.

14. Yalçin Ü., Schreyer W., Medenbach O. 1993, Zn-rich hoögbomite formed from gahnite in the metabauxites of the Menderes Massif, SW Turkey. Contributions to Mineralogy and Petrology, vol. 113, pp. 314-324.

15. Spry P. G., Petersen E. U. 1989, Zincian högbomite as an exploration guide to metamorphosed massive sulfide deposits. Mineralogical Magazine, vol. 53, issue 370, pp. 263-269. https://doi.org/10.1180/minmag.1989.053.370.15

16. Owens B. E., Belkin H. E., Zerolis J. M. 2013, Margarite, corundum, gahnite and zincohögbomite in a blackwall, Raleigh Terrane, Eastern Piedmont Province, USA. Mineralogical Magazine, vol. 77, issue 7, pp. 2913-2929. https://doi.org/10.1180/minmag.2013.077.7.03

17. Petersen E. U., Essene E. J., Peacor D. R., Marcotty L. A. 1989, The occurrence of högbomite in high-grade metamorphic rocks. Contributions to Mineralogy and Petrology, vol. 101, pp. 350-360.

The article was received on Marth 19, 2020

32 А. V. Zakharov. On the finding of zincohögbomite in the granite pegmatites of the Lipovskiy vein field (Middle Urals)//Известия УГГУ. 2020. Вып. 3(59). C. 27-34. DOI 10.21440/2307-2091-2020-3- 27-34 


\section{О находке цинкохёгбомита в гранитных пегматитах Аиповского жкильного поля (Средний Урал)}

\section{Анатолий Владимирович ЗАХАРОВ}

Институт геологии и геохимии им. акад. А. Н. Заварицкого УрО РАН, Екатеринбург, Россия

Аннотация

Aктуальность paботь обусловлена необходимостью изучения минералогии гранитных пегматитов Липовского жильного поля - уникального объекта, давшего миру большое количество кристаллосырья цветного турмалина.

Цель работь: исследование цинкохёгбомита, обнаруженного в гранитных пегматитах Липовского жильного поля (Средний Урал).

Методология исследования: количественный анализ химического состава магнетита выполнен на рентгеноспектральном электронно-зондовом микроанализаторе CAMECA SX 100 (ИГГ УрО РАН, г. Екатеринбург). Химический состав цинкохёгбомита установлен с помощью сканирующего электронного микроскопа JSM-6390LV фирмы Jeol с энергодисперсионной приставкой INCA Energy 450 X-Max 80 фирмы Oxford Instruments (ИГГ УрО РАН, г. Екатеринбург).

Результаты. При изучении поверхности кристаллов магнетита были обнаружены полости, инкрустированные уплощенными зернами неизвестного минерала в основном треугольной, реже гексагональной, формы, размером до 2-3 мкм. На основании данных по его химическому составу этот минерал был отнесен к цинкохёгбомиту. На основании кристаллохимических пересчетов установлено, что минерал соответствует цинкохёгбомиту-2H2S, или, по старой классификации, цинкохёгбомиту-8Н.

Bыводы. Установлен новый минерал для гранитных пегматитов Липовского жильного поля - цинкохёгбомит2H2S. Он был обнаружен в виде включений в индивидах магнетита в обычных внутригранитных пегматитах. Это вторая находка цинкохёгбомита на Урале и, вероятнее всего, первая в мире в гранитных пегматитах. Образование хёгбомита связывается с ретроградным метаморфизмом амфиболитовой фации, когда первичные шпинелиды становятся неустойчивыми и распадаются на несколько минеральных фаз. Образование липовского хёгбомита произошло в результате распада первичного магнетита при остывании гранитного пегматита.

Ключевые слова: цинкохёгбомит, магнетит, гранитные пегматиты, Липовское жильное поле, Средний Урал.

Автор благодарит руководство Режевского государственного природно-минералогического заказника (ОГУМПЗ «Режевской»), а также канд. геол.-минерал. наук Ю. В. Ерохина, канд. геол.-минерал. наук Л. В. Леонову и канд. геол.-минерал. наук В. В. Хиллер за помощь в проведенных исследованиях.

Работа выполнена в рамках государственного задания ИГГ УрО РАН, № гос. рег. АААА-А18-118052590032-6.

\section{ЛИТЕРАТУРА}

1. Молева В. А., Мясников В. С. О хёгбомите и его разновидности цинкхёгбомите // ДАН СССР. 1952. Т. 82, № 5. С. $733-735$.

2. Кобяшев Ю. С. Список минералов Урала (виды и разновидности) // Уральский геологический журнал. 2006. № 2 (50). С. 1-265.

3. Ерохин Ю.В., Вахрушева Н. В. О находке цинкохёгбомита-2N2S в плагиоклазитовых жилах массива Рай-Из (Полярный Урал) // VII Чтения памяти члена-корр. РАН С. Н. Иванова: материалы Всерос. науч. конф., посвящ. 70-летию основания УрО РМО. Екатеринбург: ИГГ УрО РАН, 2018. С. 66-68.

4. Емлин Э. Ф., Вахрушева Н. В., Кайнов В. И. Самоцветная полоса Урала: Режевской государственный природно-минералогический заказник: путеводитель. Екатеринбург; Реж, 2002. 156 с.

5. Пеков И. В., Меметова Л. Р. Минералы гранитных пегматитов Липовки, Средний Урал // В мире минералов. Минералогический альманах. 2008. № 13. С. 7-44.

6. Хиллер В. В., Ерохин Ю. В., Захаров А. В., Иванов К. С. Тh-U-Pb-датирование гранитных пегматитов Липовского рудного поля (Урал) по трем минералам // ДАН, 2014. Т. 455, № 2. С. 216-219.

7. Захаров А. В., Ханин Д. А. Новые данные о хризоберилле из пегматитов Липовского жильного поля (Средний Урал) // Вестник УрО PMO. 2012. № 9. C. 68-74.

8. Ханин Д. А., Захаров А. В. Гранитный пегматит с акцессорным хризобериллом из карьера № 6 Липовского силикатно-никелевого месторождения // Уральская горная школа - регионам: междунар. науч.-практ. конф. Екатеринбург: УГГУ, 2012. С. 54-55.

9. Armbruster Th. Revised nomenclature of högbomite, nigerite, and taaffeite minerals // European Journal of Mineralogy. 2002. Vol. 14. P. 389-395. https://doi.org/10.1127/0935-1221/2002/0014-0389

$\triangle$ zakharov-zav@yandex.ru

https://orcid.org/0000-0001-8790-7892 
10. Armbruster Th. Zincohogbomite-8H from Samos (Greece): crystal structure, polysomatism, and polytypism in hogbomite related structures // Schweizerische Mineralogische und Petrographische Mitteilungen. 1998. Vol. 78, № 3. P. 461-468.

11. Armbruster Th., Bermanec V., Zebec V., Oberhänsli R. Titanium and iron poor zincohögbomite- $16 \mathrm{H}, \mathrm{Zn}_{14}\left(\mathrm{Al}_{1}, \mathrm{Fe}^{3+}, \mathrm{Ti}_{1} \mathrm{Mg}_{8} \mathrm{Al}_{24} \mathrm{O}_{62}(\mathrm{OH})_{2}\right.$, from Nezilovo, Macedonia: occurrence and crystal structure of a new polysome // Schweizerische Mineralogische und Petrographische Mitteilungen. 1998. Vol. 78, № 3. P. 469-477.

12. Ockenga E., Yalçin Ü., Medenbach O., Schreyer W. Zincohögbomite, a new mineral from eastern Aegean metabauxites // European Journal of Mineralogy. 1998. Vol. 10. P. 1361-1366. URL: https://www.mindat.org/min-26091.html

13. Feenstra A. Zincohögbomite and gahnite in a diaspore-bearing metabauxite from eastern Samos (Greece): mineral chemistry, element partitioning and reaction relations // Schweizerische Mineralogische und Petrographische Mitteilungen. 1997. Vol. 77. P. 73-93.

14. Yalçin Ü., Schreyer W., Medenbach O. Zn-rich hoögbomite formed from gahnite in the metabauxites of the Menderes Massif, SW Turkey /I Contributions to Mineralogy and Petrology. 1993. Vol. 113. P. 314-324.

15. Spry P. G., Petersen E. U. Zincian högbomite as an exploration guide to metamorphosed massive sulfide deposits // Mineralogical Magazine. 1989. Vol. 53, issue 370. P. 263-269. https://doi.org/10.1180/minmag.1989.053.370.15

16. Owens B. E., Belkin H. E., Zerolis J. M. Margarite, corundum, gahnite and zincohögbomite in a blackwall, Raleigh Terrane, Eastern Piedmont Province, USA // Mineralogical Magazine. 2013. Vol. 77, issue 7. P. 2913-2930. https://doi.org/10.1180/minmag.2013.077.7.03

17. Petersen E. U., Essene E. J., Peacor D. R., Marcotty L. A. The occurrence of högbomite in high-grade metamorphic rocks // Contributions to Mineralogy and Petrology. 1989. Vol. 101. P. 350-360. 